\title{
Technology Acceptance and Future of Internet Banking in Vietnam
}

\author{
Le Duc Toan \\ Associate Professor, and Vice Provost, leductoan2002@gmail.com \\ Nguyen Huu Phu \\ Vice Provost, nhphunq@yahoo.com \\ Ho Van Nhan \\ Vice Dean of Graduate School, hovannhan@duytan.edu.vn \\ Ho Thi Phi Yen \\ Lecturer, hothiphiyen@gmail.com \\ Nguyen Quang Tam \\ Ph.D Student; nqtam1969@gmail.com \\ Duy Tan University, 03 Quang Trung, Da Nang, Vietnam \\ Le Nguyen Ngoc Anh \\ Ph.D Student, ngocanhln@yahoo.com \\ La Trobe University, Melbourne,Victoria 3086, Australia
}

\begin{abstract}
$\mathrm{T}$ he technology acceptance model (TAM) has long been applied to investigate consumer attitudes towards novel solutions and identify incentives that increase their willingness to adopt them. A cumulative tradition has already been developed in this stream of research. Using a modified TAM model, the authors explore factors that affect the intention of Vietnamese banks and their clients to adopt internet banking services. Currently, there is a number of factors hindering the diffusion of internet banking, particularly the underdevelopment of the technological infrastructure, the lack of investment, and the habits of the majority of providers and consumers of services to interact via traditional formats.

The study finds out that the adoption of internet banking could be encouraged by perceived usefulness, perceived ease of use, and, finally customer satisfaction. Among the important factors to ensure these conditions are an advanced customer support system, user-friendly interface, promptness of services, and transparency of banking operations. Among the recommendations put forward by the authors, special attention is given to the requirements for the skills of bank personnel, the need for continuous training, and the establishment of targeted strategic indicators at the public level that facilitate the embeddedness of internet banking in the life of Vietnamese society.
\end{abstract}

\section{Keywords:}

Internet banking; Technology Acceptance Model (TAM); perceived usefulness; perceived ease of use; customer satisfaction; intention to adopt; Vietnam.
Citation: Le D.T., Nguyen H.P., Ho V.N., Ho T.P.Y., Nguyen Q.T., Le N.N.A. (2018) Technology Acceptance and Future of Internet Banking in Vietnam. Foresight and STI Governance, vol. 12, no 2, pp. 36-48. DOI: $10.17323 / 2500-2597.2018 .2 .36 .48$ 
$\mathrm{T}$ he rapid development and progress of internet technology in recent years has changed our way of life. Internet banking is a service among several information systems implemented by banks in the recent past. Internet technology has given e-banking such qualities as security, fast transactions, cost reduction, and convenience. Banks can create facilities that allow customers to engage in banking activities on an electronic device on a virtual technology platform that can be used for other activities such as online shopping, stock trading, online bill payments, online auctions, and so on [Blut, 2016; Bryman, 2007].

Internet banking was launched by Vietnamese commercial banks starting in the 2010s. The number of internet users in Vietnam has rapidly increased over time. For instance, at the end of 2000 there were about 200,000 internet users ( $0.23 \%$ of total population), this number reached to 64 million (about $66.3 \%$ of the total population) in $2017^{1}$. However, the size of the e-commerce market in Vietnam has only reached about $\$ 4$ billion, which accounts for 2-3\% of the total retail value of goods. Compared with Japan and South Korea where e-commerce makes up $17 \%$ and $18 \%$ of the retail market, respectively, the share of this indicator in Vietnam does not exceed 2-3\% [Quyen, 2018]. Thus, the potential for e-commerce development is still great, especially in the context of Vietnam's integration into the global economy. Along with the increase in the number of bank cards issued and investments in payment infrastructure, now banks have begun providing the following services via online banking: money transfers, payments for electricity, water, internet, telephone, or TV cable bills. Furthermore opportunities have been arising for the use of this technology for plane ticket purchases, online shopping, and insurance payments. Despite the many benefits of using internet banking, only about $30 \%$ of commercial bank customers use internet banking in their transactions. It is clear that the adoption of internet banking services is still very low among customers of commercial banks in Vietnam. There are still large cluster of clients who prefer the traditional ways of banking, the reasons for which can be attributed to the following:

1. Vietnamese commercial banks' individual customers open accounts at banks mainly in order send and borrow money, they seldom pay fees for their transactions via internet banking. Most of these customers can understand the benefits of using internet banking but they do not have much access to online baking because they think the service is complicated and difficult to use.

2. In contrast to other markets in the world, the direct purchase of goods in Vietnam is much easier in person than online.

3. Many services in Vietnam are not part of the e-commerce market. Many restaurants do not offer online booking and retailers do not sell their goods on the internet.

4. The habit of using cash among the Vietnamese also affects the propensity to use internet banking services. People usually use cash to buy goods, go to the market, pay taxes or fees like electricity, water or even telephone fees.

5. The infrastructure for the development of internet banking is still limited, wireless internet does not have wide coverage, card payment terminals and ATM machines are usually located only in densely populated areas.

6. Commercial banks are not actively engaged in marketing the relevant services. Access to popular services remains limited, there are few resources available to help customers learn about online banking, and customer service remains much to be desired.

7. Customers are concerned about the safety and reliability of online banking services, worried about risks such as hacker attacks, financial fraud, and unpredictable events. Financial fraud usually occurs when hackers access the system, steal customer's information by searching for passwords, then making a credit transfer. Many banks in Vietnam think that they face many difficulties in detecting cheating and fraud, the main cause is the lack of financial resources or qualified human resources.

8. The lack of investments has slowed down the development of banking services. Online banking services require a large amount of capital in order to complete the development of banks' IT infrastructure and needs to meet two conditions: first, the presence of advanced and modern techniques and equipment, and, secondly, affordability (services that are affordable for people to access).

9. Commercial banks also face many difficulties regarding human resources. When implementing internet banking, each employee must equip themselves with the skills to use IT effectively, have the habit of working electronically and also be highly proficient in banking because they no longer work directly with customers. Further, banks need to have a group of IT professionals who are capable of ensuring the stable development of the online banking system.

\footnotetext{
${ }^{1}$ Internet World Stats, Usage and Population Statistics - December 2017, www.internetworldstatistic.com
} 


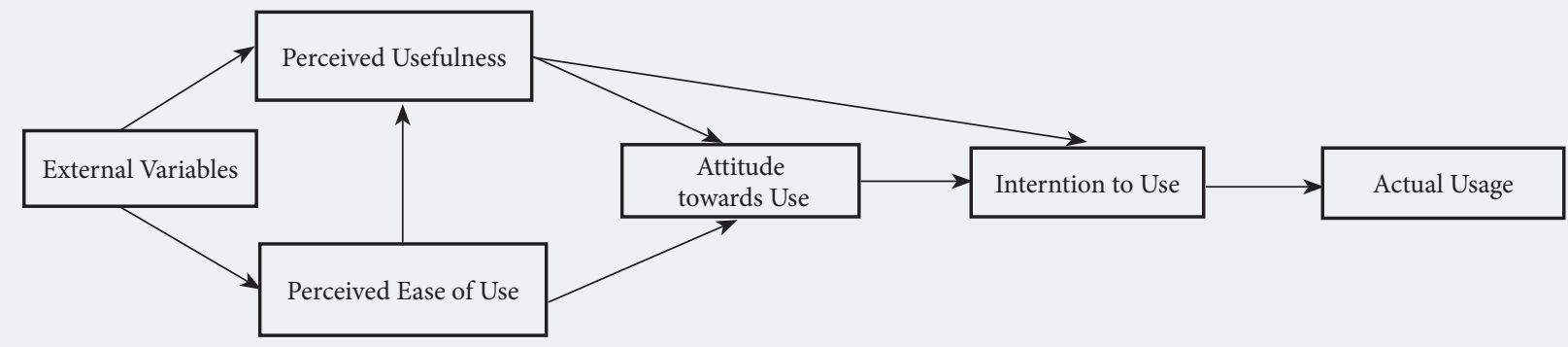

Source: compiled by the authors.

\section{Literature Review}

There are a number of previous studies about interest in internet banking, which were mostly based on the Technology Acceptance Model (TAM). TAM was first introduced by Fred Davis in 1986. His TAM was based upon an adaptation of the Theory of Reasonable Action and describes consumer behavior in the context of different information systems and technologies. After that, Davis introduced TAM 2 [Davis, 1989] in Figure 1 and TAM 3 [Venkatesh, Davis, 1996]. All three TAM models include and assess two specific beliefs: Perceived Usefulness (PU) and Perceived Ease of Use (PEU). PU is defined as the potential user's subjective belief in the likelihood that the use of a certain system will improve his/her fulfillment of tasks and PEU refers to the degree to which the potential user expects the target system to be effortless [Davis, 1989].

Foley and Jayawardhena [Foley, Jayawardhena, 2000] stipulate that internet banking brings advantages to commercial banks including cost saving, reaching customers at a global level, accessing new business strategies, and enhancing banks' performance and efficiency. Internet banking can make banking services more flexible and easy to use. Sheshunoff [Sheshunoff, 2000] suggests that when customers adopt a new technology like internet banking, this provides the bank with a competitive advantage and helps it maintain its market share. Customers that use internet banking save both money and time by avoiding long queues at banks and having the ability to conduct the necessary transactions at any time from any location.

Lichtenstein and Williamson [Lichtenstein, Williamson, 2006] interviewed individual and focus-group customers to identify trends in the consumer use of internet banking in Australia. Their results found that participants were impatient about not obtaining immediate assistance, they were not confident in their ability to find information quickly from online databases, and considered online banking difficult to use. Laukkanen et al. [Laukkanen et al., 2007] found that there are still number of bank customers using traditional ways of banking and who do not intend to adapt or accept new technologies, especially banking technologies. This initial resistance is one of the greatest barriers to the spread of internet banking. Musiime [Musiime, 2011] recognized various factors that affect the choice of customers to adopt a new technology. These factors include the experience and skill of the customer to use internet, the demographics of the user population, perceived security, market activity, the reliability of the service provider, etc.

Along with the studies based on TAM and focused on PU and PEU, there were studies that modified the TAM by adding the new determinants such as risk, security, experience, skill of usage, and customer satisfaction

Sathye [Sathye, 1999] studied the adoption of internet banking in Australia and found that security concerns about it also affected the adoption of online banking. Using the Technology Acceptance Model to examine consumer acceptance of online banking in Finland, Pikkarainen et al. [Pikkarainen et al., 2004] pointed out that concerns about security impacted online banking adoption. Many other studies have identified risk and security as important concerns for the adoption of technological innovations (e.g., [O’Connell, 1996; Polasik, Wisniewski, 2009; Venkatesh, Davis, 2000]). Waite [Waite, 2002] shows that the competitive advantages of the services, along with the ease of use, determine expectations about the accessibility of online information about retail banking services and their adoption.

Lule et al. [Lule et al., 2012] applied TAM in researching the factors that influence the adoption of mobile banking in Kenya. Confirmatory factor analysis of the data and structural equation modeling were 
Table 1. Theoretical Constructs and Hypotheses of the Study

\begin{tabular}{|c|c|c|}
\hline Construct & Description & Hypotheses suggested \\
\hline $\begin{array}{l}\text { Perceived Ease of } \\
\text { Use }\end{array}$ & $\begin{array}{l}\text { If, in the opinion of the client, the use of the system } \\
\text { (in this case internet banking) does not present any } \\
\text { difficulties, then he or she will be more inclined to use the } \\
\text { service [Hair et al., 2013, 2017] }\end{array}$ & $\begin{array}{l}\text { H1: Perceived Ease of Use has a positive influence on } \\
\text { Customer Satisfaction. } \\
\text { H2: Perceived Ease of Use has a positive influence on } \\
\text { Perceived Usefulness. }\end{array}$ \\
\hline Perceived Usefulness & $\begin{array}{l}\text { The degree to which an individual believes that using a } \\
\text { particular system will enhance his/her job performance } \\
\text { Hair et al., 2010]. Perceived usefulness has been } \\
\text { presented as the ease in conducting transactions, online } \\
\text { payments, checking financial statements, online request } \\
\text { for checks. Depending on the development of the } \\
\text { technology, other advantages may appear. }\end{array}$ & $\begin{array}{l}\text { H3: Perceived Usefulness has a positive influence on } \\
\text { Customer Satisfaction. }\end{array}$ \\
\hline Customer Service & $\begin{array}{l}\text { Customer service relates to online customer support } \\
\text { prior to, during, or after the online order has been } \\
\text { placed [Bauer et al., 2006]. Customer service is especially } \\
\text { important for internet banking clients. }\end{array}$ & $\begin{array}{l}\text { H4: Customer Service has positive influence on } \\
\text { Customer Satisfaction. } \\
\text { H5: Customer Service positively affects customers' } \\
\text { Intention to Adopt Internet Banking. }\end{array}$ \\
\hline $\begin{array}{l}\text { Customer } \\
\text { Satisfaction }\end{array}$ & $\begin{array}{l}\text { Customer Satisfaction to a great extent determines one's } \\
\text { intention to adopt internet banking. }\end{array}$ & $\begin{array}{l}\text { H6: Customer Satisfaction has a positive influence on } \\
\text { the Intention to Adopt Internet Banking. }\end{array}$ \\
\hline Mediation Analysis & $\begin{array}{l}\text { Mediation occurs when a third mediator variable } \\
\text { interferes in the cooperation of two other constructs. } \\
\text { This study tests whether there are mediator variables } \\
\text { between the following constructs: Customer Service } \\
\text { and the Intention to Adopt Internet Banking; Perceived } \\
\text { Usefulness and the Intention to Adopt Internet Banking. }\end{array}$ & $\begin{array}{l}\text { H7: Customer Satisfaction mediates the relationship } \\
\text { between Customer Service and the Intention to } \\
\text { Adopt Internet Banking. } \\
\text { H8: Customer Satisfaction mediates the relationship } \\
\text { between Perceived Usefulness and the Intention to } \\
\text { Adopt Internet Banking. } \\
\text { H9: Customer Satisfaction mediates the relationship } \\
\text { between Perceived Ease of Use and the Intention to } \\
\text { Adopt Internet Banking. }\end{array}$ \\
\hline
\end{tabular}

used to validate the research model. The results found that perceived ease of use, perceived usefulness, perceived efficacy, and perceived credibility significantly influenced customers' attitude towards the use of mobile banking.

Geetha and Malarvizhi [Geetha, Malarvizhi, 2012] carried out an assessment of a modified Technology Acceptance Model among e-banking customers in India. Their study determined the factors influencing the consumer's adoption of e-banking in India, which include perceived ease of use, perceived usefulness, and perceived risk. The results suggest that Indian commercial banks need to highlight the benefits of e-banking, make it easy to use, and ensure its security to improve consumers' trust.

Alsamydai [Alsamydai, 2014] adapted the TAM to study the use of mobile banking services in Jordan. In his study, the TAM model was modified by introducing two new dimensions, quality and experience, to the five dimensions of TAM model, which was introduced by Davis [Davis, 1986]. The results show a positive correlation between all of these components and demonstrate the strong correlation between the attitude toward and the use of mobile banking services. Among these dimensions, the strongest correlation was found between perceived ease of use and experience.

Ghani et al. [Ghani et al., 2017] investigated the technology acceptance model (TAM) for internet banking and focused on the dimensions of customer service and customer satisfaction. Their study shows that the intention to adopt internet banking could be encouraged by perceived ease of use, perceived usefulness, customer services, and customer satisfaction. The result also demonstrates that customer satisfaction takes on a significant mediating role among the proposed variables. An importance performance matrix analysis (further, IPMA) test demonstrated that customer service is the most important factor.

In order to supply a theoretical basis for researching the adoption of internet banking, in this study the TAM model has been modified by integrating two new dimensions, which are customer service and customer satisfaction (Figure 2). With the help of the modified TAM, a deep analysis of the state of the banking sector in Vietnam will be carried out with a focus on the use of internet banking services.

The main goals of this study are as follows:

- To evaluate the contribution of the modified TAM in assessing the readiness of customers to use internet banking

- To investigate the opportunity of using and influence of the two new factors included in the model.

The constructs and hypotheses of this study are synthesized in Table 1. 
Table 2. Constructs and Indicators Used in the Study

\begin{tabular}{|c|c|c|}
\hline & Factors and indicators & Epoxy \\
\hline I & Perceived Ease of Use & \\
\hline 1 & $\begin{array}{l}\text { Most of the Vietnamese population is used to using cash and think that using cash is easier than internet } \\
\text { banking }\end{array}$ & PE1 \\
\hline 2 & In order to use internet banking, I need to have knowledge about information technology & PE2 \\
\hline 3 & In order to use internet banking services, I need serious help and support on the bank's portal & PE3 \\
\hline 4 & Interaction with the system requires a great deal of mental effort & PE4 \\
\hline II & Perceived Usefulness & \\
\hline 1 & I do not need to the bank on a regular basis & PU1 \\
\hline 2 & Using internet banking saves me a lot of time & PU2 \\
\hline 3 & I can manage my money online at any time & PU3 \\
\hline 4 & I can save time paying bills at the post office and the airport & PU4 \\
\hline 5 & Using internet banking services raises my status compared to those who do not. & PU5 \\
\hline III & Customer Service & \\
\hline 1 & Vietnam commercial banks seldom provide online support to customers using internet banking. & CS1 \\
\hline 2 & $\begin{array}{l}\text { The infrastructure for internet banking is still lacking, many restaurants have not offered online booking and the } \\
\text { stores do not have the necessary card terminals and devices for using internet banking. }\end{array}$ & CS2 \\
\hline 3 & The internet banking system has effective tools to help me resolve problems & CS3 \\
\hline 4 & $\begin{array}{l}\text { Vietnamese commercial banks should invest more in the improvement of technologies used to detect fraud and } \\
\text { information theft }\end{array}$ & CS4 \\
\hline IV & Customer Satisfaction & \\
\hline 1 & I am not particularly worried about the risks of hacker attacks or financial fraud when using internet banking & SA1 \\
\hline 2 & In Vietnam, the infrastructure of internet banking is still limited, there is limited wireless coverage & SA2 \\
\hline 3 & I am satisfied with my previous internet banking experience & SA3 \\
\hline $\mathbf{V}$ & Intention to Adopt Internet Banking & \\
\hline 1 & I intend to start using internet banking services in the near future & INT1 \\
\hline 2 & I predict that I will start using internet banking service in the near future & INT2 \\
\hline 3 & In the future, I intend to use internet banking whenever I have a need & INT3 \\
\hline
\end{tabular}

\section{Materials and Methods}

In this study, internet banking is used to describe banking transactions via mobile, ATM, and tablet apps. For data collection, the convenience sampling method was used as supported by Hair et al. [Hair et al., 2013, 2014] because this method allows the researcher to receive responses in a cost-effective way [Martins, 2014]. The investigated individual customers of Sacombank own smartphones and tablet apps and they can implement banking transactions via mobile, ATM, and tablet apps. The constructs and the indicators of this study are shown in Table 2. The five-point Likert scale was used in the questionnaire ( $\mathrm{SD}$ - strongly disagree, $\mathrm{D}$ - disagree, $\mathrm{N}$ - neutral, A - agree, SA - strongly agree) for the collection of primary data. The responders' demographic characteristics are provided in Table 3.

The survey was conducted from November 2017 to December 2017 in Vietnam with 195 respondents, in which, there are 20 surveys unfit for analysis, leaving 175 samples that are suitable for analysis. Among the 175 individual customers, some use internet banking and some do not. The percentage of users and non-users of internet banking is depicted in Table 2 .

Data collected from survey were analyzed by using SmartPLS 3. PLS-SEM (partial least squares-structural equation modeling) allowed the researchers to estimate any complex model with many constructs and indicator variables, especially when prediction is the goal of the analysis. Furthermore PLS-SEM generally allows for more flexibility in terms of data requirements and the specification of relationships between constructs and indicator variables [Sarstedt et al., 2017]. PLS - SEM is a nonparametric statistical method. Different from maximum likelihood (ML)-based CB-SEM, it does not require the data to be normally distributed [Hair et al., 2017]. PLS-SEM relies on a bootstrap procedure to test coefficients for their significance [Davison, Hinkley, 1997]. Prior research stated that a sample size of 100 to 200 is usually a good starting point in carrying out path modeling [Hoyle, 1995].

This study uses reflective measurement constructs, it includes five: Customer Service, Perceived Ease of Use, Perceived Usefulness, Customer Satisfaction, and Intention to Adopt (Figure 2).The measurement model has 19 indicators, but PU5 and CS4 indicators were eliminated because their outer loadings are smaller than 0.70 . 


\section{Figure 2. Theoretical Framework}

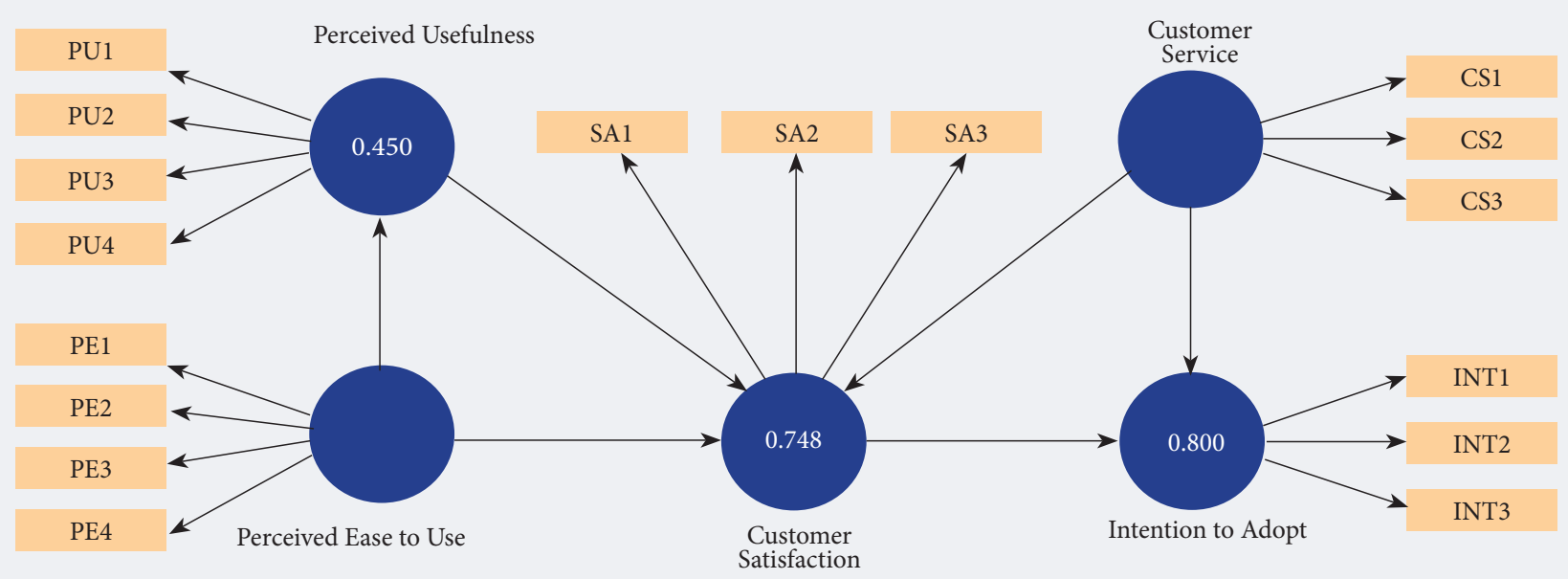

Source: compiled by the authors.

\begin{tabular}{|c|c|}
\hline Categories & Percentage \\
\hline \multicolumn{2}{|c|}{ Gender } \\
\hline Male & $54 \%$ \\
\hline Female & $46 \%$ \\
\hline \multicolumn{2}{|c|}{ Age } \\
\hline Less than 25 years old & $32.2 \%$ \\
\hline $26-35$ years old & $34.6 \%$ \\
\hline $36-45$ years old & $22 \%$ \\
\hline More than 46 years old & $11.2 \%$ \\
\hline \multicolumn{2}{|c|}{ Education } \\
\hline High school education & $36 \%$ \\
\hline In college & $20 \%$ \\
\hline Bachelor or post-graduate degree & $44 \%$ \\
\hline Source: compiled by the authors. & \\
\hline
\end{tabular}

Table 4. Percentage of Respondents that Use or Do Not Use Internet Banking

\begin{tabular}{|l|c|c|}
\hline \multicolumn{1}{|c|}{ Answers } & Frequency & Percent \\
\hline Yes & 50 & $30 \%$ \\
\hline No & 125 & $70 \%$ \\
\hline Total & 175 & $100 \%$ \\
\hline \multicolumn{2}{|l}{ Source: Survey Result, 2017} \\
\hline
\end{tabular}

\section{Table 6. R Squared}

\begin{tabular}{|l|c|c|}
\hline & R Squared & R Squared Adjusted \\
\hline Intention to Adopt & 0.800 & 0.797 \\
\hline Perceived Usefulness & 0.450 & 0.445 \\
\hline Customer Satisfaction & 0.748 & 0.741 \\
\hline Source: compiled by the authors. \\
\hline
\end{tabular}

\section{Figure 3. Measurement Model}

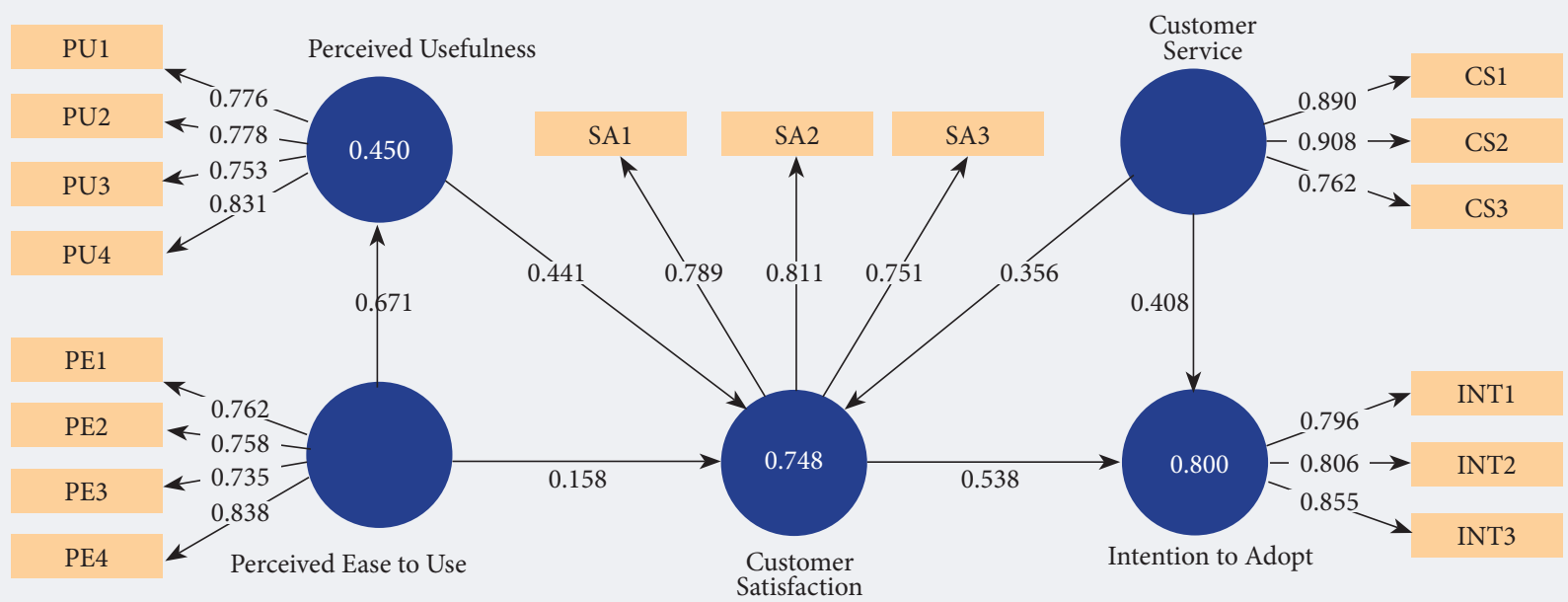

Source: compiled by the authors. 
Table 5. Outer Loadings

\begin{tabular}{|c|c|c|c|c|c|}
\hline Question code & $\begin{array}{l}\text { Perceived Ease } \\
\text { of Use }\end{array}$ & $\begin{array}{l}\text { Perceived } \\
\text { Usefulness }\end{array}$ & $\begin{array}{l}\text { Customer } \\
\text { Service }\end{array}$ & $\begin{array}{c}\text { Customer } \\
\text { Satisfaction }\end{array}$ & $\begin{array}{c}\text { Intention to } \\
\text { Adopt }\end{array}$ \\
\hline PE1 & 0.762 & & & & \\
\hline PE2 & 0.758 & & & & \\
\hline PE3 & 0.735 & & & & \\
\hline $\mathrm{PE} 4$ & 0.838 & & & & \\
\hline PU1 & & 0.776 & & & \\
\hline PU2 & & 0.778 & & & \\
\hline PU3 & & 0.753 & & & \\
\hline PU4 & & 0.831 & & & \\
\hline CS1 & & & 0.890 & & \\
\hline $\mathrm{CS} 2$ & & & 0.908 & & \\
\hline CS3 & & & 0.762 & & \\
\hline SA1 & & & & 0.789 & \\
\hline SA2 & & & & 0.811 & \\
\hline SA3 & & & & 0.751 & \\
\hline INT1 & & & & & 0.796 \\
\hline INT2 & & & & & 0.806 \\
\hline INT3 & & & & & 0.855 \\
\hline
\end{tabular}

\section{Measurement Model}

To evaluate the convergent validity of the reflective constructs, the study analyzes the outer loading of the indicators and the average variance validity. The outer loadings of all indicators should be statistically significant and the standardized outer loading should be above 0.70 . The square of a standardized indicator's outer loading represents how much variation in an item is explained by the construct and is described as the variance extracted from the item.

An established rule of thumb is that a latent variable should explain a substantial part of each indicator's variance, usually at least $50 \%$. This means that an indicator's outer loading should be above 0.708 based on the square of that number $\left(0.708^{2}=0.50\right)$. $\mathrm{R}^{2}$ value of $0.75,0.50$, or 0.25 for endogenous latent variables can be respectively described a substantial, moderate, or weak [Henseler et al., 2009]. The R-Square values are shown inside the blue ellipse for endogenous latent variables (Figure 3). For the endogenous variable Intention to Adopt, the $\mathrm{R}$ Square value is 0.80 , meaning that about $80 \%$ of the variance in Intention to Adopt is explained by the model (Table 6); this is a substantial level.

Cronbach's Alpha: Cronbach's Alpha values in this reflective measurement construct are larger than 0.677, and thus ensure reliability (Table 7). Cronbach's Alpha is the traditional criterion for internal consistency, which provides an estimate of reliability based on the intercorrelations of the observed indicator variables. Cronbach's Alpha assumes that all indicators are equally reliable, but PLS-SEM prioritizes the indicators according to their individual reliability and moreover Cronbach's Alpha is sensitive to the number of the items in the sample and generally tends to underestimate the internal consistency reliability. In this case a different measure of internal consistency reliability can be used, Composite Reliability [Hair et al., 2017]. The composite reliability (CR) method depicts the degree to which the construct indicators represent the latent constructs. With a value of 0.981 (Customer Service), 0.857 (Perceived Ease of Use), 0.865

Table 7. Construct Reliability and Validity

\begin{tabular}{|l|c|c|c|}
\hline & Cronbach's Alpha & $\begin{array}{c}\text { Composite } \\
\text { Reliability }\end{array}$ & $\begin{array}{c}\text { Average Variance } \\
\text { Extracted (AVE) }\end{array}$ \\
\hline Customer Service & 0.814 & 0.891 & 0.732 \\
\hline Intention to Adopt & 0.755 & 0.860 & 0.671 \\
\hline Perceived Ease of Use & 0.777 & 0.857 & 0.599 \\
\hline Perceived Usefulness & 0.792 & 0.865 & 0.616 \\
\hline Customer Satisfaction & 0.688 & 0.827 & 0.615 \\
\hline Source: compiled by the authors.
\end{tabular}




\section{Table 8. Confidence Intervals Bias Corrected}

\begin{tabular}{|l|c|c|c|c|c|}
\hline & $\begin{array}{c}\text { Original } \\
\text { Sample (O) }\end{array}$ & Sample Mean (M) & Bias & $\mathbf{2 . 5 \%}$ & $\mathbf{9 7 . 5 \%}$ \\
\hline Perceived Ease of Use $\rightarrow$ Customer Satisfaction & 0.158 & 0.159 & 0.000 & 0.040 & 0.288 \\
\hline Perceived Ease of Use $\rightarrow$ Perceived usefulness & 0.671 & 0.677 & 0.006 & 0.552 & 0.750 \\
\hline Perceived Usefulness $\rightarrow$ Customer Satisfaction & 0.441 & 0.439 & -0.002 & 0.259 & 0.606 \\
\hline Customer Service $\rightarrow$ Customer Satisfaction & 0.356 & 0.359 & 0.003 & 0.202 & 0.499 \\
\hline Customer Service $\rightarrow$ Intention to Adopt & 0.408 & 0.408 & 0.000 & 0.293 & 0.528 \\
\hline Customer Satisfaction $\rightarrow$ Intention to Adopt & 0.538 & 0.537 & 0.000 & 0.415 & 0.648 \\
\hline Source: compiled by the authors. & & & \\
\hline
\end{tabular}

(Perceived Usefulness), 0.827 (Satisfaction) and 0.860 (Intention to Adopt), all five reflective constructs have a high level of internal consistency reliability.

Discriminant validity: Discriminant validity is the extent in which a construct is truly distinct from other constructs by empirical standards. Thus, establishing discriminant validity implies that a construct is unique and captures phenomena not represented by other constructs in the model. A common measure to establish convergent validity on the construct level is average variance extracted (AVE). An AVE value of 0.50 or higher is accepted, which means that the construct explains more than half of the variance of its indicators. Other approaches can be used to assess the discriminant validity of the indicators, for example, the Fornell-Larcker criterion [Fornell, Larcker, 1981] and the Heterotrait Monotrait Ratio (HTMT). HTMT is used in this study. Henseler et al. [Henseler et al., 2015] suggest a threshold value of 0.90 if the path model includes constructs that are conceptually very similar. In other words, an HTMT value above 0.90 suggests a lack of discriminant validity. The HTMT can serve as the basis of a statistical discriminant validity test. In this study, we rely on a procedure called bootstrapping to derive a distribution of the HTMT statistic.

The lower and upper bound of the confidence interval of HTMT for the relationship between Perceived Ease of Use and Customer Service are 0.04 and 0.228, respectively (Table 8). Similarly, the lower and upper bound of the confidence interval of HTMT for the relationship between Customer Service and Customer Satisfaction are 0.202 and 0.499 . Thus all HTMT values of five constructs in the study are smaller than 0.90 . Thus, the reflective measurement construct possesses discriminant validity.

Confidence intervals: We need to analyze the outer weights for their significance and relevance. We first consider the significance of the outer weights by means of bootstrapping. Bootstrap confidence intervals provide further information about the stability of the model estimates. Researchers should draw on the bias correction method to construct bootstrap confidence intervals.

In Table 8, the estimated path coefficients of the reflective measurement model do not include zero, then we confirm the significant effects and that their values indicate the extent to which the exogenous constructs are associated with the endogenous constructs.

Inner Variance Inflation Factor (VIF) Value: PLS-SEM is a distribution-free multivariate data analysis technique and, as such, does not rely on distributional assumptions. As a consequence, it is different from, for example, an Ordinary Least Squares (OLS) regression, PLS-SEM does not initially provide $t$ or $p$ values to evaluate the estimates' significance. Instead, this study has to rely on the bootstrapping procedure that provides bootstrap standard errors.

Table 9. Inner VIF Value

\begin{tabular}{|l|c|c|c|c|c|}
\hline & Customer Satisfaction & Customer Service & $\begin{array}{c}\text { Intention to } \\
\text { Adopt }\end{array}$ & Perceived Ease of Use & Perceived Usefulness \\
\hline $\begin{array}{l}\text { Customer } \\
\text { Satisfaction }\end{array}$ & & & 2.630 & & \\
\hline Customer Service & & & 2.630 & & 1.000 \\
\hline Intention to Adopt & & & & & \\
\hline $\begin{array}{l}\text { Perceived Ease of } \\
\text { Use }\end{array}$ & & & & & \\
\hline Perceived Usefulness & 2.810 & & & & \\
\hline Source: compiled by the authors.
\end{tabular}


Table 10. Path Coefficients

\begin{tabular}{|c|c|c|c|c|c|c|}
\hline Hypotheses & $\begin{array}{c}\text { Original } \\
\text { Sample } \\
(\text { O) }\end{array}$ & $\begin{array}{l}\text { Sample Mean } \\
\text { (M) }\end{array}$ & $\begin{array}{l}\text { Standard } \\
\text { Deviation } \\
\text { (STDEV) }\end{array}$ & T-Statistics & P-Values & $\begin{array}{l}\text { Is the } \\
\text { Hypothesis } \\
\text { Valid? }\end{array}$ \\
\hline $\begin{array}{l}\text { H1: Perceived Ease of Use } \rightarrow \text { Customer } \\
\text { Satisfaction }\end{array}$ & 0.158 & 0.159 & 0.064 & 2.468 & $\begin{array}{c}0.014 \\
(<0.02)\end{array}$ & Yes \\
\hline $\begin{array}{l}\text { H2: Perceived Ease of Use } \rightarrow \text { Perceived } \\
\text { usefulness }\end{array}$ & 0.671 & 0.677 & 0.049 & 13.796 & $\begin{array}{c}0.000 \\
(<0.01)\end{array}$ & Yes \\
\hline $\begin{array}{l}\text { H3: Perceived Usefulness } \rightarrow \text { Customer } \\
\text { Satisfaction }\end{array}$ & 0.441 & 0.439 & 0.089 & 4.970 & $\begin{array}{c}0.000 \\
(<0.01)\end{array}$ & Yes \\
\hline $\begin{array}{l}\text { H4: Customer Service } \rightarrow \text { Customer } \\
\text { Satisfaction }\end{array}$ & 0.356 & 0.359 & 0.076 & 4.655 & $\begin{array}{l}0.000 \\
(<0.01)\end{array}$ & Yes \\
\hline $\begin{array}{l}\text { H5: Customer Service } \rightarrow \text { Intention to } \\
\text { adopt }\end{array}$ & 0.408 & 0.408 & 0.060 & 6.786 & $\begin{array}{l}0.000 \\
(<0.01)\end{array}$ & Yes \\
\hline $\begin{array}{l}\text { H6: Customer Satisfaction } \rightarrow \text { Intention to } \\
\text { Adopt }\end{array}$ & 0.538 & 0.537 & 0.060 & 8.925 & $\begin{array}{l}0.000 \\
(<0.01)\end{array}$ & Yes \\
\hline
\end{tabular}

The study first assesses the lateral collinearity of constructs. Collinearity occurs when two variables that are hypothesized to be causally related measure the same construct. Diamantopoulos and Siguaw [Diamantopoulos, Siguaw, 2006] stated that values of VIF 3.3 or higher indicate potential collinearity. The results of inner VIF values are shown in Table 9. According to the results in Table 9, Perceived Usefulness has the highest inner VIF value (2.810), hence, inner VIF values are uniformly below the threshold value of $5 \%$.

\section{Results}

\section{Hypothesis Testing}

The bootstrapping procedure was used to assess the significance and relevance of the structural model relationships. When an empirical $t$-value is larger than the critical value, we conclude that coefficient is statistically significant with a certain error probability. Commonly used critical values for two-tailed tests are 1.65 (significance level=10\%), 1.96 (significance level=5\%), and 2.57 (significance level=1\%) [Hair, 2017]. The results in Table 10 depict the path coefficients of the respective constructs with their level of significance in order to validate some of the considered hypotheses.

The relationship between perceived ease of use and customer satisfaction is accepted by H1: (t-statistic $=$ $2.468, \mathrm{p}<0.02)$. Hereafter, the relationship between perceived ease of use and perceived usefulness is supported by $\mathrm{H} 2$ : (t-statistic $=13.796, \mathrm{p}<0.01)$

Following, $\mathrm{H} 3$ showed that perceived usefulness is positively related to customer satisfaction (t-statistic $=$ 4.970, $\mathrm{p}<0.01)$. The relationship between customer service and customer satisfaction is accepted by H4: $(\mathrm{t}$-statistic $=4.655, \mathrm{p}<0.01)$. The relationship between customer service and intention to adopt internet banking is accepted by H5: (t-statistic $=6.786, \mathrm{p}<0.01)$. Meanwhile, the relationship between customer satisfaction and intention to adopt internet banking is supported by H6: $(\mathrm{t}$-statistic $=8.925, \mathrm{p}<0.01)$.

\section{Total Indirect Effects and Total Effects}

The study need to evaluate not only one construct's direct effect on another, but also its indirect effects via one or more mediating constructs [Hair, 2017]. The direct effects are the relationships linking constructs with a single arrow. Indirect effects are those relationships that involve a sequence of relationships with

\section{Table 11. Total Indirect Effects}

\begin{tabular}{|l|c|c|c|c|c|}
\hline & $\begin{array}{c}\text { Original } \\
\text { Sample (O) }\end{array}$ & $\begin{array}{c}\text { Sample Mean } \\
(\mathbf{M})\end{array}$ & $\begin{array}{c}\text { Standard } \\
\text { Deviation } \\
(\text { STDEV) }\end{array}$ & $\begin{array}{c}\text { T-Statistics } \\
(\mid \mathbf{O} / \text { STDEV|) }\end{array}$ & P-values \\
\hline Customer Service $\rightarrow$ Intention to Adopt & 0.191 & 0.192 & 0.039 & 4.870 & 0.000 \\
\hline Perceived Ease of Use $\rightarrow$ Customer Satisfaction & 0.296 & 0.297 & 0.065 & 4.529 & 0.000 \\
\hline Perceived Ease of Use $\rightarrow$ Intention to Adopt & 0.244 & 0.247 & 0.052 & 4.655 & 0.000 \\
\hline H9: Perceived Usefulness $\rightarrow$ Intention to Adopt & 0.237 & 0.238 & 0.062 & 3.814 & 0.000 \\
\hline \multicolumn{2}{|l|}{ Source: compiled by the authors. }
\end{tabular}


Table 12. Direct, Indirect and Total Effects on Intention to Adopt

\begin{tabular}{|l|c|c|c|}
\hline & Direct Effect & Indirect Effect & Total Effect \\
\hline Customer Service & 0.408 & 0.191 & 0.599 \\
\hline Perceived Usefulness & - & 0.237 & 0.237 \\
\hline Perceived Ease of Use & - & 0.520 & 0.520 \\
\hline Customer Satisfaction & 0.538 & - & 0.538 \\
\hline Source: compiled by the authors. & & \\
\hline
\end{tabular}

at least one intervening construct involved. All the indirect effects in Table 10 have significance at a level of 5\% (Figure 3, Table 11, Table 12).

Customer Service and Intention to Adopt are linked by a direct effect $(=0.408)$ and an indirect effect $(0.356 \times 0.538=0.1915)$. Then, the total effect is: $0.408+0.191=0.599$. In the same way, the total effect of Perceived Ease of Use and Customer Satisfaction is: $0.158+(0.671 \times 0.441)=0.454$. The total effect of Perceived Usefulness to Intention to Adopt is: 0.2372 . The total effect of Perceived Ease of Use to Intention to Adopt is 0.520 .

\section{Mediation Analysis}

Mediation occurs when a third mediator variable intervenes between two other related constructs [Hair, 2017]. More precisely, a change in the exogenous construct causes a change in the mediator variable, which, in turn, results in a change in the endogenous construct in the PLS path model. Thereby, a mediator variable governs the nature of the relationship between two constructs.

This study analyzes the significance of the indirect effect of Customer Service on Intention to Adopt via the mediator variable (Customer Satisfaction). If the indirect effect is not significant, we conclude that Customer Satisfaction does not function as a mediator in the tested relationship. From Figure 3 and Table 11, it follows that Perceived Usefulness serves as mediator variable in the relationship between Perceived Ease of Use and Customer Satisfaction. The latter in turn may foster Intention to Adopt along with Customer Service.

From the aforementioned results, hypothesis $\mathrm{H} 7, \mathrm{H} 8$ and $\mathrm{H} 9$ are accepted.

Thus, the results of proposed hypothesis revealed that, all nine hypotheses have a significant relationship with their respective endogenous variables.

\section{Evaluating Effect Size}

The size of the $\mathrm{f}^{2}$ effect enables us to analyze the relevance of the constructs in explaining the selected endogenous constructs. In addition to evaluating the $\mathrm{R}^{2}$ value of all endogenous constructs, the change in the $\mathrm{R}^{2}$ value when a specified exogenous construct is omitted from the model can be used to evaluate whether the omitted construct has a substantive impact on the endogenous constructs. This measure is referred to as the $\mathrm{f}^{2}$ effect size and is increasingly encouraged by journal editors and reviewers. Guidelines for assessing $\mathrm{f}^{2}$ are that values of $0.02,0.15$ and 0.35 , respectively, represent the small, medium, and large effects of the exogenous latent variable. Effect size values of less than 0.02 indicate that there is no effect [Cohen, 1988]. All $\mathrm{f}^{2}$ in this suggested model are larger than 0.02 (e.g., the effect size of the construct Customer Satisfaction on the endogenous latent variable Intention to Adopt is 0.551), therefore, the omitted construct has a substantive impact on the endogenous construct (Table 13).

\section{Table 13. f-Square}

\begin{tabular}{|l|l|l|l|l|l|}
\hline & Customer Satisfaction & $\begin{array}{c}\text { Customer } \\
\text { Service }\end{array}$ & $\begin{array}{c}\text { Intention to } \\
\text { Adopt }\end{array}$ & $\begin{array}{c}\text { Perceived Ease of } \\
\text { Use }\end{array}$ & $\begin{array}{c}\text { Perceived } \\
\text { Usefulness }\end{array}$ \\
\hline Customer Satisfaction & & & 0.551 & & \\
\hline Customer Service & 0.204 & & 0.317 & & \\
\hline Intention to Adopt & & & & & 0.817 \\
\hline Perceived Ease of Use & 0.052 & & & & \\
\hline Perceived Usefulness & 0.275 & & & \\
\hline Source: compiled by the authors.
\end{tabular}


Table 14. Summary of the IPMA Data

\begin{tabular}{|l|c|c|}
\hline & Importance & Performance \\
\hline Customer Service & 0.599 & 39 \\
\hline Perceived Usefulness & 0.237 & 61 \\
\hline Perceived Ease of Use & 0.520 & 50 \\
\hline Customer Satisfaction & 0.538 & 49 \\
\hline Source: compiled by the authors. & \\
\hline
\end{tabular}

\section{Importance Performance Matrix Analysis (IPMA)}

The IPMA compares the structural model's total effects on a specific target construct (Intention to Adopt) with the average latent variable scores of this construct's predecessors (Customer Service, Customer Satisfaction, Perceived Usefulness, Perceived Ease of Use). The total effects represent the predecessor constructs' importance in shaping the Intention to Adopt while their average latent variable scores represent their performance. The goal is to identify the predecessors that have relatively high importance for Intention to Adopt but also a relatively low performance

The aspects underlying these constructs represent a potential area for improvement that may be of interest. Using the IPMA data allows us to create an important performance map as shown in Figure 4. The $\mathrm{x}$-axis represents the (unstandardized) total effects of Customer Service, Customer Satisfaction, Perceived Usefulness on the target construct (Intention to Adopt). The y-axis depicts the average rescaled (unstandardized) latent variable scores of Customer Service, Customer Satisfaction, and Perceived Usefulness.

Table 14 shows the index values and total effect scores. It can be seen that Customer Service is the most important factor in determining the Intention to Adopt internet banking due to its higher importance values compared to other latent variables. Customer Satisfaction and Perceived Ease of Use also are the important factors, while Perceived Usefulness has the lowest level of importance. The Importance Performance Matrix map (Figure 4) showed that customer service has the highest potential to influence customers considering the adoption of internet banking, the constructs customer satisfaction and perceived ease of use demonstrated intermediate importance and performance compared with other constructs. In other words, the managers of commercial banks need to focus on improving the performance of customer service, customer satisfaction, and the perceived ease of use.

\section{Conclusions and Recommendations}

In the study, the technology acceptance model has been modified by integrating two new dimensions, which are customer service and customer satisfaction. The suggested model, aimed at assessing the

Figure 4. IPMA

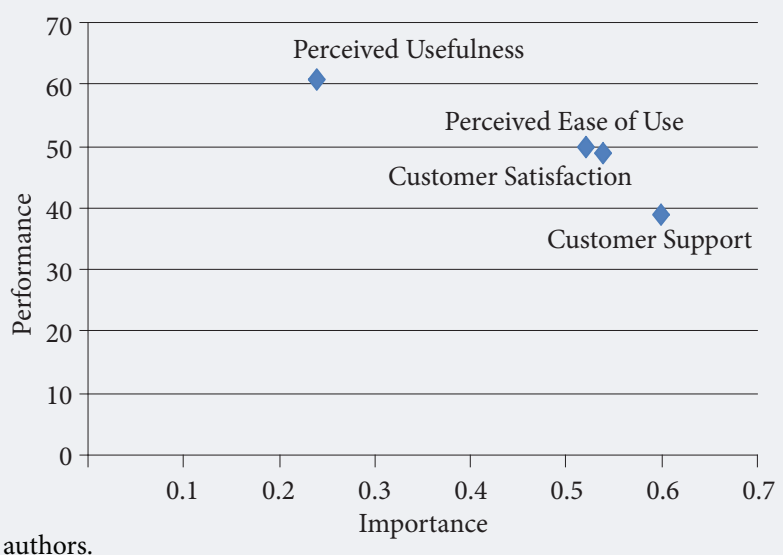


Table 15. Strategic Targets for the Development of the Banking Sector in Vietnam

\begin{tabular}{|l|c|c|c|}
\hline \multicolumn{1}{|c|}{ Planning horizon } & $\begin{array}{c}\text { Type of payments } \\
\text { accepted via banks }\end{array}$ & $\begin{array}{c}\text { Service providers (target } \\
\text { share) }\end{array}$ & $\begin{array}{c}\text { Service consumers } \\
\text { (target share) }\end{array}$ \\
\hline 2020 & $\begin{array}{c}\text { Payment for medical } \\
\text { services }\end{array}$ & $\begin{array}{c}\text { Hospitals in large cities } \\
(50 \%)\end{array}$ & Patients (-) \\
\hline 2022 & Tuition fees & $\begin{array}{c}\text { Universities and colleges } \\
(100 \%)\end{array}$ & Students (80\%) \\
\hline 2025 & $\begin{array}{c}\text { Power and water bill } \\
\text { payments }\end{array}$ & $\begin{array}{c}\text { Suppliers }(80 \%) \\
\text { Households in large } \\
\text { cities (50\%) }\end{array}$ \\
\hline \multicolumn{2}{|l|}{ Source: compiled by the authors. }
\end{tabular}

intention to adopt internet banking in Vietnam, included five constructs with 17 indicators. The results find that the study's model ensures the indicator reliability, composite reliability, and discriminant validity. For the endogenous variable Intention to Adopt, the R Squared value is 0.80 , meaning that about $80 \%$ of the variance in Intention to Adopt is explained by the model (which is a substantial level).

Implementing the IPMA and $\mathrm{f}^{2}$ effect, the study also derives that a change in the exogenous construct causes a change in the mediator variable, which, in turn, results in a change in the endogenous construct in the PLS path model. The omitted construct (if such occurs) will have a substantial impact upon the endogenous construct. All nine hypotheses of the study were confirmed and the study reveals that customer service is the most important factor in determining a customer's intention to adopt internet banking due to its higher importance values compared to other latent variables. The constructs customer satisfaction and perceived ease of use demonstrated intermediate importance and performance. Overall, the study shows that the integration of the two new elements in the technology acceptance model was a good fit and that analyzing the reflective measurement constructs can bring new ideas to the management of Vietnamese commercial banks.

In order to encourage clients to continue to use internet banking services, the bank must explain to them the advantages of such mechanisms, in particular the opportunities to save both time and money. An easy-to-use interface must be developed for informing customers who are new to the service, simple and clear instructions must be prepared, and clients must be informed about their transactions in a timely manner. It is necessary to constantly work to update and provide relevant information on the bank's website, which should be regularly checked by bank managers to receive client feedback.

Restaurants and stores need to be equipped with devices for processing non-cash payments. In addition, businesses such as those in the medical, dairy, home improvement, and office supplies sectors should not ignore the development of e-commerce.

In order to develop internet banking services in Vietnam, it is important to create and promote a good business environment, provide socioeconomic stability, invest in the development of infrastructure, improve living standards, promote the provision and use of modern services, and discourage the habit of using cash. The Vietnamese government needs to build a legal framework for internet banking and e-banking services. The State Bank of Vietnam should coordinate with the Ministry of Public Security to take measures to promptly prevent and stop crime, ensure the information security (including the protection of customer passwords when carrying out bank transactions), protect customers' interests, and reduce risks and losses for the banks themselves.

Furthermore, the Vietnamese government is developing regulations to promote non-cash payments throughout the period of 2018-2025 and is working to develop e-government regulations and enhance the use of banking services. In particular, 80\% of tax payments in cities are to be made via banks by 2022 . For some other strategic targets, see Table 15.

The management of Sacombank must focus on continuously improving the knowledge and professional qualifications of its staff so that they can fully understand the products and services offered, confidently inform clients, and sell products. It is important to attentively listen to all complaints and wishes of clients, to thoroughly study and comprehend them, and to provide timely feedback, which will help banks objectively assess the work they do.

Finally, it is possible to add other constructs to the model used in this article for the study of the behavior of customers of Vietnamese banks, in particular, Comprehension of Risks and Brand Value. 


\section{References}

Alsamydai M.J. (2014) Adaptation of the TAM to the use of mobile banking services. International Review of Management and Business Research, vol. 3, no 4, pp. 2016-2028.

Bauer H.H., Falk T., Hammerschmidt M. (2006) eTransQual: A transaction process-based approach for capturing service quality in online shopping. Journal of Business Research, vol. 59, no 7, pp. 866-875.

Blut M. (2016) E-Service Quality: Development of a Hierarchical Model. Journal of Retailing, vol. 92, no 4, pp. 500-517.

Bryman A.B. (2007) Business Research Methods, Oxford: Oxford University Press.

Cohen J. (1988) Statistical power analysis for the behavioural sciences ( $2^{\text {nd }}$ ed.), Hillside Mahwah, NJ: Lawrence Erlbaum.

Davis F.D. (1986) A technology acceptance model for empirically testing new end-user information systems: Theory and results, Cambridge, MA: Massachusetts Institute of Technology.

Davis F.D. (1989) Perceived usefulness, perceived ease of use and user acceptance of information technology. MIS Quarterly, vol. 13, no 3, pp. 319-340.

Davis F.D., Bagozzi R.P., Warshaw P.R. (1989) User acceptance of computer technology: A comparison of two theoretical models. Management Science, vol. 35, no 8, pp. 982-1003.

Davison A.C., Hinkey D.V. (1997) Bootstrap methods and their application, Cambridge, UK: Cambridge University Press.

Diamantopoulos A., Siguaw J.A. (2006) Formative versus reflective indicators in measure development: Does the choice of indicators matter? British Journal of Management, vol. 17, no 4, pp. 263-282.

Foley P., Jayawardhena C. (2000) Changes in the banking sector-the case of Internet banking in the UK. Internet Research, vol. 10, no 1, pp. 19-30.

Fornell C., Larcker D.F. (1981) Evaluating Structural Equation Models with Unobservable Variables and Measurement Error. Journal of Marketing Research, vol. 18, no 1, pp. 39-50.

Geetha K., Malarvizhi V. 2012) Assessment of a Modified Technology Acceptance Model among E-banking Customers in Coimbatore City. International Journal of Innovation, Management and Technology, vol. 3, no 2, pp. 181-187.

Ghani M.M., Rahi S., Yasin N., Alnaser F.M. (2017) Adoption of Internet Banking: Extending the Role of Technology Acceptance Model (TAM) with E-Customer Service and Customer Satisfaction. World Applied Sciences Journal, vol. 35, no 9, pp. 1918-1929.

Hair J.F., Black W.C., Babin B.J., Anderson R.E., Tatham R.L. (2010) Multivariate Data Analysis (7 ${ }^{\text {th }}$ ed.), Upper Saddle River, NJ: Prentice Hall.

Hair J.F., Hult G.T., Ringle C.M., Sarstedt M. (2017) A primer on partial least squares structural equation modeling (2nd ed.), Thousand Oaks, CA: SAGE Publications.

Hair J.F., Hult G.T.M., Ringle C., Sarstedt M. (2013) A Primer on Partial Least Squares Structural Equation Modeling (PLS-SEM), Thousand Oaks, CA: SAGE Publications.

Hair J.F., Sarstedt M., Hopkins L., Kuppelwieser G.V. (2014) Partial least squares structural equation modeling (PLS-SEM): An emerging tool in business research. European Business Review, vol. 26, no 2, pp. 106-121.

Henseler J., Ringle C.M., Sarstedt M. (2015) A new criterion for assessing discriminant validity in variance-based structural equation modeling. Academy of Marketing Science Journal, vol. 43, no 1, pp. 115-127.

Henseler J., Ringle C.M., Sinkovics R.R. (2009) The use of partial least squares path modeling in international marketing. Advances in International Marketing, vol. 20, pp. 277-320.

Hoyle R.H. (ed.) (1995) Structural Equation Modeling, Thousand Oaks, CA: SAGE Publications.

Laukkanen P., Sinkkonen S., Kivijarvi M. and Laukkanen T. (2007) Consumer Resistance and Intention to use Internet banking service. Paper presented at the EBRF Conference, Jyvaskyla, Finland, September 25.

Lichtenstein S., Williamson K. (2006) Understanding Consumer Adoption of Internet Banking: An Interpretive Study in the Australian Banking Context. Journal of Electronic Commerce Research, vol. 7, no 2, pp. 50-66.

Lule I., Omwansa T.K., Waema T.M. (2012) Application of Technology Acceptance Model (TAM) in M-Banking Adoption in Kenya. International Journal of Computing and ICT Research, vol. 6, no 1, pp. 31-43.

Martins C., Oliveira T., Popovie A. (2014) Understanding the Internet banking adoption: A unified theory of acceptance and use of technology and perceived risk application. International Journal of Information Management, vol. 34, no 1, pp. 1-13.

Musiime A., Ramadhan M. (2011) Interment banking consumer adoption and customer satisfaction. African Journal of Marketing Management, vol. 3, no 10, pp. 261-269.

O'Connell B. (1996) Australian Banking on the Internet-Fact or Fiction? The Australian Banker, December, pp. 212-214.

Pikkarainen K., Karjaluoto H., Pahnila S. (2004) Consumer acceptance of online banking: An extension of the technology acceptance model. Internet Research, vol. 14, no 3, pp. 224-235.

Polasik K., Wisniewski T. (2009) Empirical Analysis of Internet Banking Adoption in Poland. International Journal of Bank Marketing, vol. 27, no 1, pp. 32-52. DOI: 10.1108/02652320910928227.

Quyen D.V. (2018) E-commerce: Much room left for growth. The Saigon Times, no 13 (1381), March 24, 2018.

Sarstedt M., Ringle C.M., Hair J.F. (2017) Partial Least Squares Structural Equation Modeling. Handbook of Market Research (eds. C. Homburg, M. Klarmann, A. Vomberg), Heidelberg; New York; Dordrecht; London: Springer (print version forthcoming). DOI: 10.1007/978-3-319-05542-8_15-1. Available at: http://www.researchgate.net/ publication/319669432, accessed 02.05.2018.

Sathye M. (1999) Adoption of Internet Banking by Australian Consumers: An Empirical Investigation. International Journal of Bank Marketing, vol. 17, no 7, pp. 324-334.

Sheshunoff A. (2000) Internet banking: An update from the frontlines. ABA Banking Journal, vol. 92, no 1, pp. 51-53.

Venkatesh V., Davis F.D. (1996) A model of the antecedents of perceived ease of use: Development and test. Decision Sciences, vol. 27, no 3, pp. 451-481.

Venkatesh V., Davis F.D. (2000) Theoretical extension of the technology acceptance model: Four longitudinal field studies. Management Science, vol. 46, no 2, pp. 186-204.

Waite K., Harrison T. (2002) Consumer Expectations of Online Information Provided by Bank Websites. Journal of Financial Services Marketing, vol. 6, no 4, pp. 309-322. Available at: http://dx.doi.org/10.1057/palgrave. fsm.4770061, accessed 17.04.2018. 